\title{
Copris hispanus cavolinii (Coleoptera: Scarabaeidae) in the Collection of "Grigore Antipa" National Museum of Natural History (Bucharest)
}

\author{
Andreea-Cătălina DRĂGHICI ${ }^{*}$
}

\begin{abstract}
"Grigore Antipa" National Museum of Natural History, Bucharest, Romania.
*corresponding author, e-mail: andreea.draghici@antipa.ro
\end{abstract}

Received: December 13, 2016; Accepted: May 6, 2017; Available online: May 24, 2017; Printed: June 30, 2017

\begin{abstract}
Copris hispanus cavolinii (Petagna, 1792) is mentioned for the first time in the Coleoptera Collection of "Grigore Antipa" National Museum of Natural History (Bucharest). Three new records are added in the present short note for $C$. hispanus cavolinii based on the studied material.
\end{abstract}

Key words: Coleoptera, Copris hispanus cavolinii, Romania, records

Up to now three species of Copris are recorded in Romanian fauna: Copris lunaris (Linnaeus), C. hispanus (Linnaeus) and C. umbilicatus Abeille de Perrin. First of them is a very common species, the second one was known only from BreșnitaOcol, Mehedinți County (Ruicănescu, 1993), and the third was recorded only from Băile Herculane. The specimen of C. umbilicatus is preserved in the Collection of the Museum of Natural History of Wien, Austria (Ziani et al., 2015). Copris hispanus includes two subspecies, Copris hispanus hispanus (Linnaeus, 1764) and Copris hispanus cavolinii (Petagna, 1792). Copris cavolinii was initially described as species by Petagna from Italy; other authors (Král \& Bezděk, 2016) have considered it a subspecies of $C$. hispanus. Later, Falahee \& Angus (2010) expressed the opinion that it should be considered as a distinct species, on the basis of karyological studies.

362 specimens of Copris from the Scarabaeidae Collection (study collection) have been studied. The identification was made using the external morphological characteristics (Paulian, 1941). 358 specimens belong to Copris lunaris (Linnaeus), and four specimens belong to C. hispanus cavolinii (Petagna). Three specimens of C. h. cavolinii were collected from Romania: the first male from Cheile Dobrogei, Cheia Jurasic Reef, Constanța County, 13.04.2015, leg. Gabriel Chișamera, the second male was colected from Ivrinezu Mare, Constanța County, 03.04.2017, leg. Viorel Gavril, and a female from Urziceni, Ialomița County, 28.07.1966, leg. Nicolae Săvulecu (Fig. 1). The fourth specimen, a male, was collected from Tolfa Mountains (Italy), on 06.04.1974.

The three species of Copris genus can be differentiated by:

- Copris hispanus: the anterior margin of the pronotum is bisinuate; the anterior angle of the pronotum is almost rectangular; unitary, shield-like anterior face of the pronotum; the male has a large curved horn on the head, the female, a smaller one;

- Copris lunaris: the anterior margin of the pronotum is not sinuate; the anterior angle of the pronotum is broadly rounded; the anterior face of the pronotum has two clear-cut lateral indentations instead of a shield-like pronotum; a pointed horn in the male, a very short, bifide horn in the female (Fig. 2). 


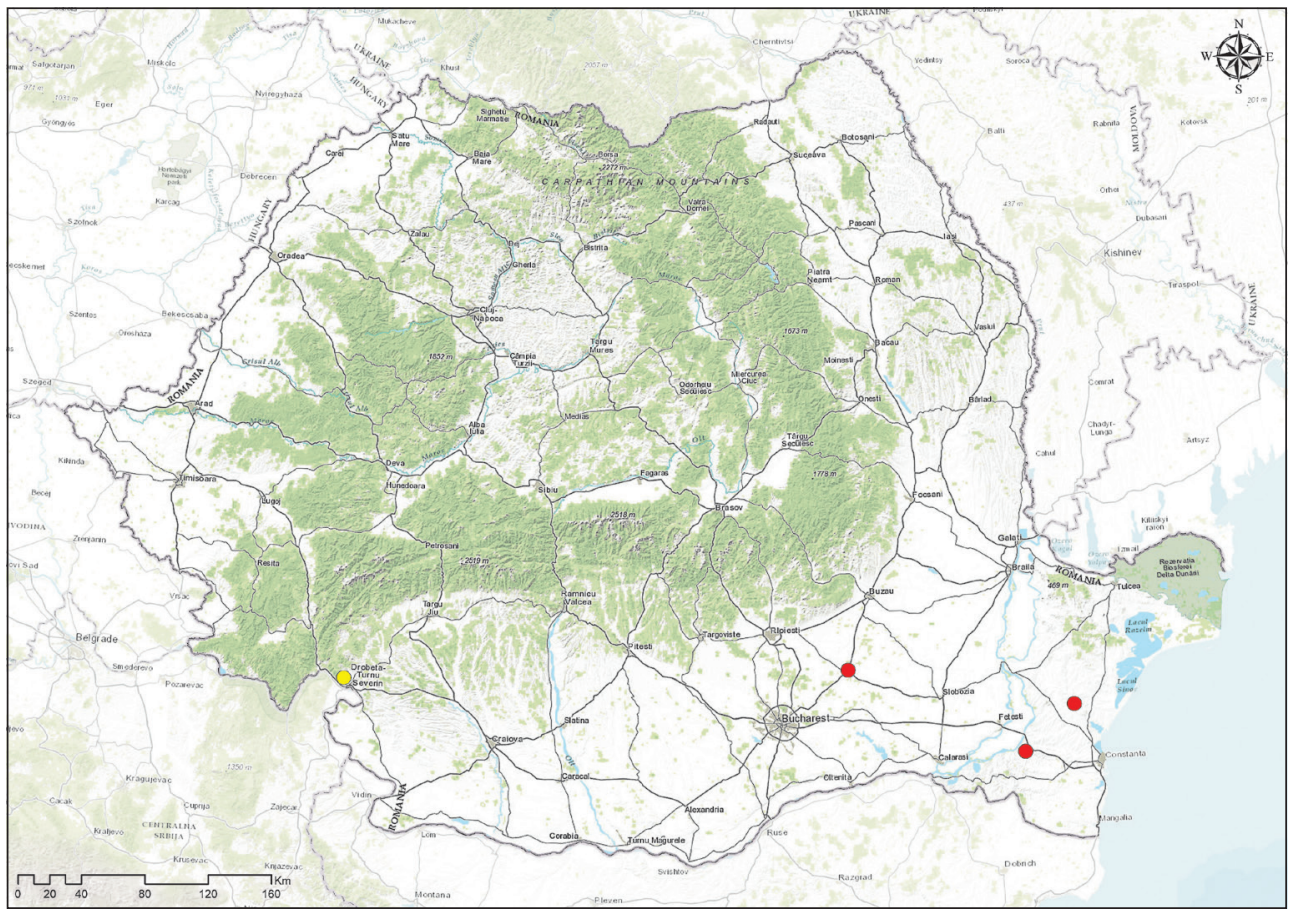

Fig. 1 - Collecting sites of Copris hispanus cavolinii in Romania: new records (red dots) and former record (yellow dot)

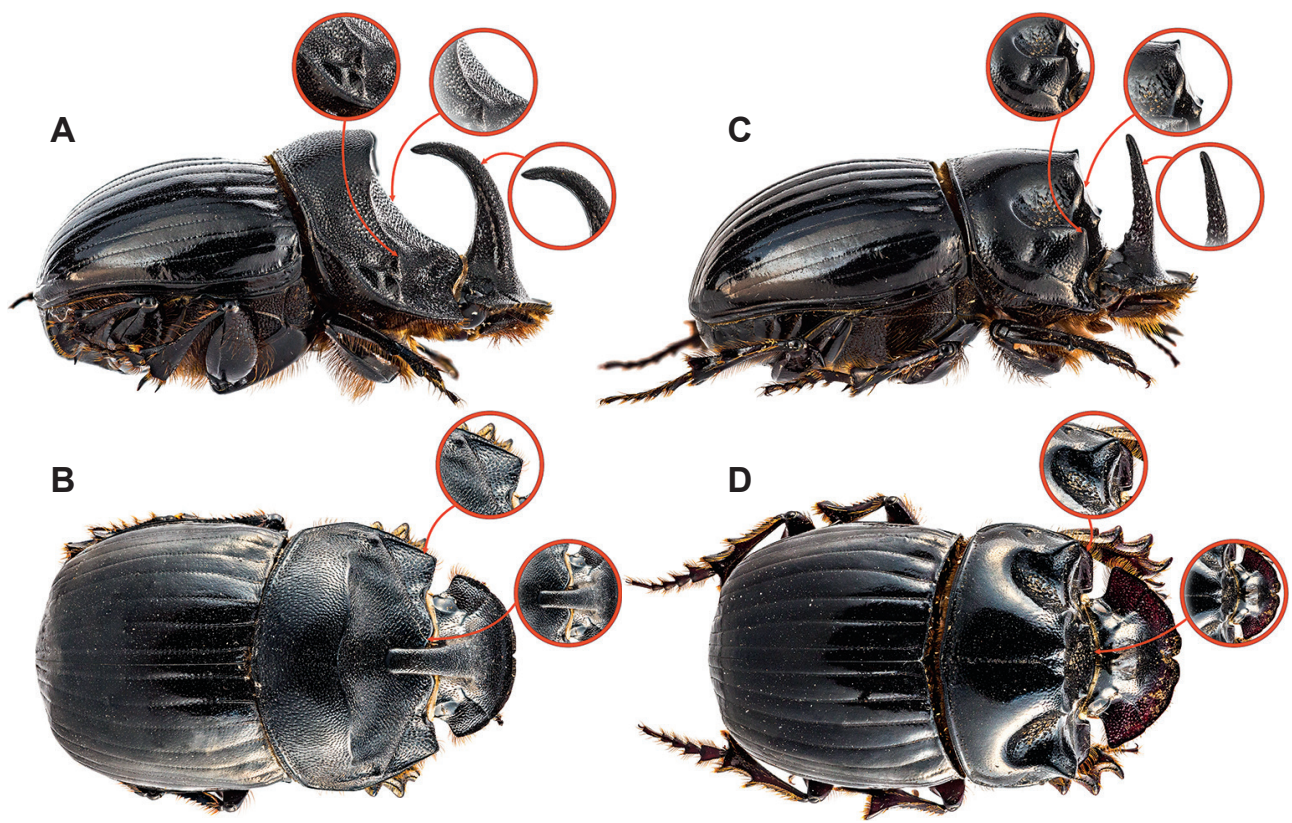

Fig. 2 -Copris hispanus cavolinii: A, male, lateral view; B, male, dorsal view; Copris lunaris: C, male, lateral view; D, male, dorsal view. Scale: $1 \mathrm{~mm}$ (Photos: I. Ș. Iorgu) 
- Copris umbilicatus: three teeth at outer margin of fore tibia, relatively small hornlike appendage of pronotum, metasternal plate with median longitudinal groove ending with a deep fovea, and (in males) without denticles at base of epistomal horn.

The two subspecies of Copris hispanus are differentiated by the carina of the pronotum: deeply sinuated in $C$. h. hispanus and not sinuated in Copris $h$. cavolinii and by the presence of the antero-lateral dentations found in $C$. $h$. hispanus, absent in Copris h. cavolinii.

\section{ACKNOWLEDGEMENTS}

I am grateful to Dr. Melanya Stan (“Grigore Antipa” National Museum of Natural History) and Dr. Adrian Ruicănescu (Institut of Biological Research, Cluj-Napoca) for their scientific support, to Dr. Ionuț Iorgu and Dr. Tiberiu Sahlean for the photographs of the specimens and for the map of collecting sites.

\section{REFERENCES}

FALAHEE, S. L., R. B. ANGUS (2010) Chromosomal separation of difficult species of Copris Geoff roy, 1762 and Onthophagus Latreille, 1802 (Coleoptera, Scarabaeidae), with discussion of O. massai Baraud as a British Pleistocene fossil. In: E. B. Ratcliff, F.T. Krell (eds) Current advances in Scarabaeoidea research. ZooKeys 34: 17-32.

KRÁL, D., A. BEZDĚK (2016) Tribe Coprini Leach, 1815. In: I. Löbl, D. Löbl (eds.) Catalogue of Palaearctic Coleoptera. Volume 3, Scarabaeoidea, Scirtoidea, Dascilloidea, Buprestoidea, Byrrhoidea Description: Revised and updated edition. Leiden ; Boston : Brill, pp. 168-171.

PAULIAN, R. (1941) Faune de France. Coléoptères Scarabeidés. 38, 240 pp. (in French)

RUICĂNESCU, A. (1993) Copris hispanus (L.) (Coleoptera: Scarabaeidae), new species in fauna of Romania. Studii și cercetări de biologie, seria Biologie animală, 44(1): 3-6.

ZIANI, S., A. BEZDĚK, T. BRANCO, O. HILLERT, S. JÁKL (2015) New country records of Scarabaeoidea (Coleoptera) from the Palaearctic Region. Insecta Mundi 0409: 1-36. 